\title{
Starmerella bombicola and Saccharomyces cerevisiae in Wine Sequential Fermentation in Aeration Condition: Evaluation of Ethanol Reduction and Analytical Profile
}

\author{
Laura Canonico, Edoardo Galli, Alice Agarbati, Francesca Comitini and Maurizio Ciani *iD
}

check for

updates

Citation: Canonico, L.; Galli, E.; Agarbati, A.; Comitini, F.; Ciani, M. Starmerella bombicola and Saccharomyces cerevisiae in Wine Sequential Fermentation in Aeration Condition: Evaluation of Ethanol Reduction and Analytical Profile. Foods 2021, 10, 1047. https:// doi.org/10.3390/foods10051047

Academic Editors: Roberto Carmine Foschino and Ileana Vigentini

Received: 6 April 2021

Accepted: 7 May 2021

Published: 11 May 2021

Publisher's Note: MDPI stays neutra with regard to jurisdictional claims in published maps and institutional affiliations.

Copyright: (C) 2021 by the authors Licensee MDPI, Basel, Switzerland. This article is an open access article distributed under the terms and conditions of the Creative Commons Attribution (CC BY) license (https:// creativecommons.org/licenses/by/ $4.0 /)$.
Dipartimento Scienze della Vita e dell'Ambiente, Università Politecnica delle Marche, Via Brecce Bianche, 60131 Ancona, Italy; 1.canonico@univpm.it (L.C.); e.galli@pm.univpm.it (E.G.); a.agarbati@pm.univpm.it (A.A.); f.comitini@univpm.it (F.C.)

* Correspondence: m.ciani@univpm.it; Tel.: +39-071-2204987

Abstract: In the last few decades, the increase of ethanol in wine, due to global climate change and consumers' choice is one of the main concerns in winemaking. One of the most promising approaches in reducing the ethanol content in wine is the use of non-Saccharomyces yeasts in cofermentation or sequential fermentation with Saccharomyces cerevisiae. In this work, we evaluate the use of Starmerella bombicola and S. cerevisiae in sequential fermentation under aeration condition with the aim of reducing the ethanol content with valuable analytical profile. After a preliminary screening in synthetic grape juice, bench-top fermentation trials were conducted in natural grape juice by evaluating the aeration condition $(20 \mathrm{~mL} / \mathrm{L} / \mathrm{min}$ during the first $72 \mathrm{~h})$ on ethanol reduction and on the analytical profile of wines. The results showed that S. bombicola/S. cerevisiae sequential fermentation under aeration condition determined an ethanol reduction of $1.46 \%(v / v)$ compared with $S$. cerevisiae pure fermentation. Aeration condition did not negatively affect the analytical profile of sequential fermentation S. bombicola/S. cerevisiae particularly an overproduction of volatile acidity and ethyl acetate. On the other hand, these conditions strongly improved the production of glycerol and succinic acid that positively affect the structure and body of wine.

Keywords: ethanol reduction; Starmerella bombicola; oxygen; wine; analytical profile

\section{Introduction}

Ethanol is the main product in wine produced by yeast during alcoholic fermentation. During the last two decades, in many different geographical areas, the average alcohol level has risen about $2 \%(v / v)$ [1].

Generally, the alcohol level in wine is between 12 and $14 \%(v / v)$ with some exception the different varieties of wines [2].

The climatic changes recorded in recent years have resulted in grapes with high sugar concentrations, which is reflected in wines with increased ethanol content. Wines with high ethanol content are associated with health issues, economic and quality aspects [3-12].

Indeed, high alcohol levels in wine compromise the organoleptic properties of the product increasing the hotness and viscosity, and decreasing sweetness, intensity, and aromatic flavors [13-20]. The combination of these aspects (organoleptic, economic and health issues) in wine with high ethanol content has led to the development of technological strategies to produce wines with a reduced alcohol level without affecting flavour profile and sensorial characteristics [21]. For these reasons, many strategies in reduce ethanol content in wine during the winemaking process have been proposed, such as viticultural, pre-fermentation, fermentation and post fermentation practices $[1,8,22,23]$.

A suitable strategy for reducing the alcohol level of wine is the use of non-Saccharomyces yeasts able to use different pathways for sugar convert (respiration, alcoholic fermentation, and glycerol-pyruvic metabolism) [24-26]. Biotechnological processes under different 
fermentation conditions with non-Saccharomyces in co-culture or sequential fermentation with S. cerevisiae starter strain were proposed [22,27-32].

In sequential inoculation, the non-Saccharomyces yeast strain is inoculated in the grape juice in the first stage of fermentation $(48-72 \mathrm{~h}$ ). This procedure allows the nonSaccharomyces strain to take advantage favouring its metabolic activity. In particular, the non-Saccharomyces yeasts could affect the wines by producing a low ethanol yield, low volatile acidity and/or enhancement of specific analytical and aromatic compounds [33-36]. Different researches showed that the physiological features of Metschnikowia pulcherrima Lachancea thermotolerans, Torulaspora delbrueckii, Starmerella and Zygosaccharomyces spp. strains are suitable for lower ethanol content in wine in the presence of oxygen. According with the results obtained by controlled aeration fermentations the ethanol reduction was for M. pulcherrima $1.6 \%(v / v)$, T. delbrueckii $0.9 \%(v / v)$, Z. bailii $1.0 \%(v / v)$, and S. bacillaris $0.7 \%(v / v)$ compared with S. cerevisiae wine $[31,37]$. In recent previous work, Starmerella bombicola (formerly Candida stellata) was evaluated for ethanol reduction in wine in a static condition and in a immobilized form with promising results [32]. However, immobilized cells are a modality of inoculum, quite complex and difficult to apply under an industrial vinification condition.

Previously, a strain of S. bombicola was proposed to enhance the glycerol content of wine in immobilized form to overcome its low fermentation rate [38]. Indeed, the general enological traits of $S$. bombicola strains showed low fermentation rate and low fermentation power ( $4-5 \%$ vol. of ethanol) together with some interesting positive features as high glycerol and succinic acid production.

In the present work, with the aim to reduce the ethanol content in wine, S. bombicola/S. cerevisiae sequential fermentations were evaluated under partial aeration condition. The analytical composition and aromatic profile of the final wines were also evaluated.

\section{Materials and Methods}

\subsection{Yeast Strains}

The non-Saccharomyces yeast strain used in this study was S. bombicola DiSVA 66 (formerly named Candida stellata DBVPG 3827; Industrial Yeast Collection of the University of Perugia) and evaluated in a previous work in immobilized form [32]. S. cerevisiae commercial strain Lalvin EC1118 (Lallemand Inc., Toulouse, France) was used in pure (control) and sequential fermentation trials. These strains were maintained on YPD agar medium ( $1 \%$ yeast extract, $2 \%$ peptone, $2 \%$ D-glucose, and $1.8 \%$ agar) at $25^{\circ} \mathrm{C}$ for $48 \mathrm{~h}$, and stored at $4{ }^{\circ} \mathrm{C}$.

\subsection{Preliminary Screening on Synthetic Grape Juice (SGJ)}

Modified YPD medium ( $0.5 \%$ yeast extract, $0.1 \%$ peptone, $2 \%$ dextrose, all $w / v)$ was used to obtain biomass for fermentation trials. S. bombicola cells were incubated at $25^{\circ} \mathrm{C}$ for $72 \mathrm{~h}$ in a rotary shaker $(150 \mathrm{rpm})$. This biomass was harvested by centrifugation, washed three times with sterile distilled water.

To optimize the cell concentration of S. bombicola, screening was conducted on SGJ, and prepared according to the protocol reported by Ciani and Ferraro [38]. The trials were carried out in $100 \mathrm{~mL}$ flask containing $70 \mathrm{~mL}$ SGJ under static and agitation condition (200 rpm rotary shaker) at $22 \pm 1{ }^{\circ} \mathrm{C}$ in triplicate. The inoculum of $S$. bombicola was $1 \times 10^{8}$ cells $/ \mathrm{mL}$ and $5 \times 10^{7}$ cells $/ \mathrm{mL}$ followed three days, by S. cerevisiae $\left(1 \times 10^{6}\right.$ cells $\left./ \mathrm{mL}\right)$. Ethanol content, volatile acidity and glycerol content were analyzed. The fermentation trial, which showed the best reduction in alcohol content was selected to set up fermentation in Natural Grape Juice (NGJ).

\subsection{Natural Grape Juice (NGJ) Fermentation Trials}

Natural grape juice (NGJ) (Verdicchio white grape variety), used for trials, showed the following characteristics: $\mathrm{pH}, 3.32$; total acidity, $5.17 \mathrm{~g} / \mathrm{L}$; free $\mathrm{SO}_{2}, 9 \mathrm{mg} / \mathrm{L}$; total $\mathrm{SO}_{2}$, 
$18 \mathrm{mg} / \mathrm{L}$; malic acid, $3.1 \mathrm{~g} / \mathrm{L}$; initial sugar content, $218 \mathrm{~g} / \mathrm{L}$; yeast assimilable nitrogen (YAN) $121 \mathrm{mg} \mathrm{N} / \mathrm{L}$.

The 2-L Bench-top bioreactor (Biostat ${ }^{\circledR}$ B; B. Braun Biotech Int., Goettingen, Germany) containing $1.5 \mathrm{~L}$ of natural grape juice under gentle agitation $(60 \mathrm{rpm} / \mathrm{min})$ was used for fermentation trials. The temperature was $22^{\circ} \mathrm{C}$ with an inoculation level of $5 \times 10^{7}$ cells $/ \mathrm{mL}$ of $S$. bombicola obtained using the procedure described above. Aerobic condition was maintained using $20 \mathrm{~mL} / \mathrm{L} / \mathrm{min}$ of air flow during the initial $72 \mathrm{~h}$, while in semi-anaerobic condition no aeration was applied. In sequential fermentations, S. cerevisiae was inoculated after $72 \mathrm{~h}\left(1 \times 10^{6}\right.$ cells $\left./ \mathrm{mL}\right)$. Pure fermentations of $S$. cerevisiae (inoculum $1 \times 10^{6}$ cells $/ \mathrm{mL}$ ) were used as controls under gentle agitation $(60 \mathrm{rpm} / \mathrm{min}$, semi-anaerobic condition).

A specific enzymatic kit (Megazyme International Wicklow Ireland) was used to evaluate the sugar consumption during the fermentation to monitor fermentation kinetics. Biomass evolution was evaluated by viable cell count $(\mathrm{CFU} / \mathrm{mL})$ on Lysine Agar selective medium and WL nutrient agar (Oxoid, Hampshire, UK) [39]. Wild non-Saccharomyces yeasts (WNS) were easily distinguished by S. bombicola through a macro- and microscopic characterization of colony on WL nutrient agar. The fermentations were carried out in triplicate.

\subsection{Analytical Procedures}

Total acidity, volatile acidity, $\mathrm{pH}$ and ethanol content were determined according to the Official European Union Methods [40]. The final samples, prepared following the procedure of Canonico et al. [41], were directly injected into a gas chromatography system (GC-2014; Shimadzu, Kjoto, Japan) to quantify acetaldehyde, ethyl acetate, n-propanol, isobutanol, amyl and isoamyl alcohols. Solid-phase microextraction (HS-SPME) method with the fiber. Divinylbenzene/Carboxen/Polydimethylsiloxane (DVB/CAR/PDMS) (Sigma-Aldrich, St. Louis, MO, USA) was used to determine the main volatile compounds desorbed by inserting the fiber into gas chromatograph GC (GC-2014; Shimadzu, Kjoto, Japan) The compounds were identified and quantified using external calibration curves [42].

Glucose and fructose (K-FRUGL), glycerol (K-GCROL) and succinic acid (K-SUCC) were analyzed using specific enzyme kits (Megazyme International, Wicklow Ireland).

\subsection{Statistical Analysis}

Experimental data for the main analytical characters of wine have been subjected to analysis of variance (ANOVA) using the statistical software package JMP ${ }^{\circledR} 11$. Duncan test was used to determine the significant differences ( $p$-values were $<0.05$ ).

\section{Results}

\subsection{Preliminary Screening on Synthetic Grape Juice}

The results of the ethanol content of screening trials, carried out under static and agitation conditions, was reported in Figure 1A.

S. bombicola/S. cerevisiae sequential fermentation in agitation condition significant enhanced the ethanol reduction if compared with static one and S. cerevisiae pure culture both in static and agitation condition. In particular, S. bombicola/S. cerevisiae sequential fermentation $10^{8}$ cells $/ \mathrm{mL}$ and $5 \times 10^{7}$ cells $/ \mathrm{mL}$ achieved an ethanol reduction of $1.25 \%(v / v)$, and $1.05 \%(v / v)$, respectively in comparison with $S$. cerevisiae pure culture (in both conditions). Moreover, the ethanol content in the trials with inoculum level $5 \times 10^{7}$ cells $/ \mathrm{mL}$ in agitation condition was comparable with that obtained with $10^{8}$ cells $/ \mathrm{mL}$. 


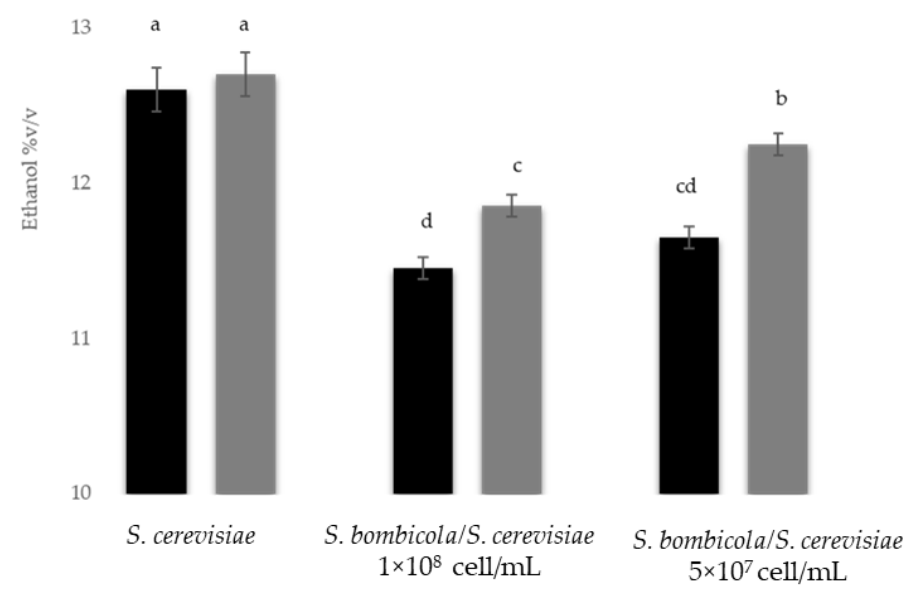

(A)
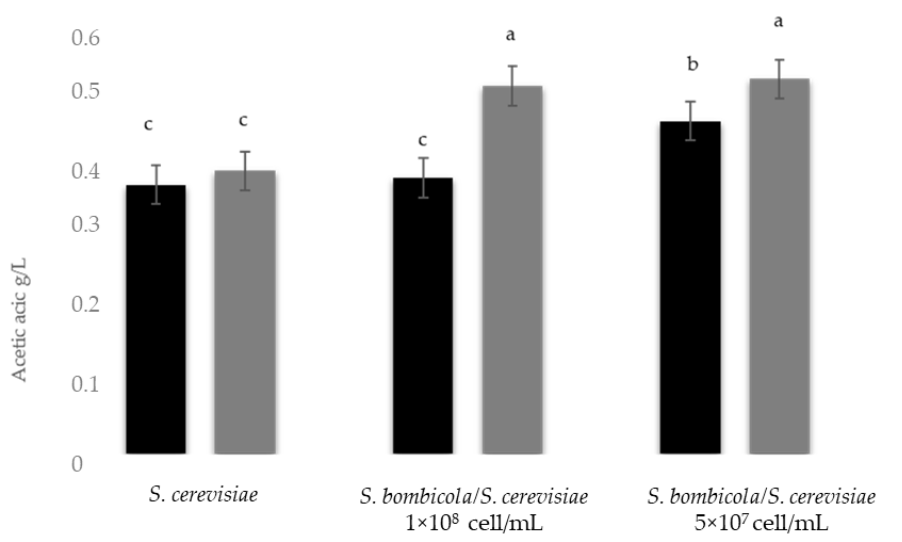

(B)

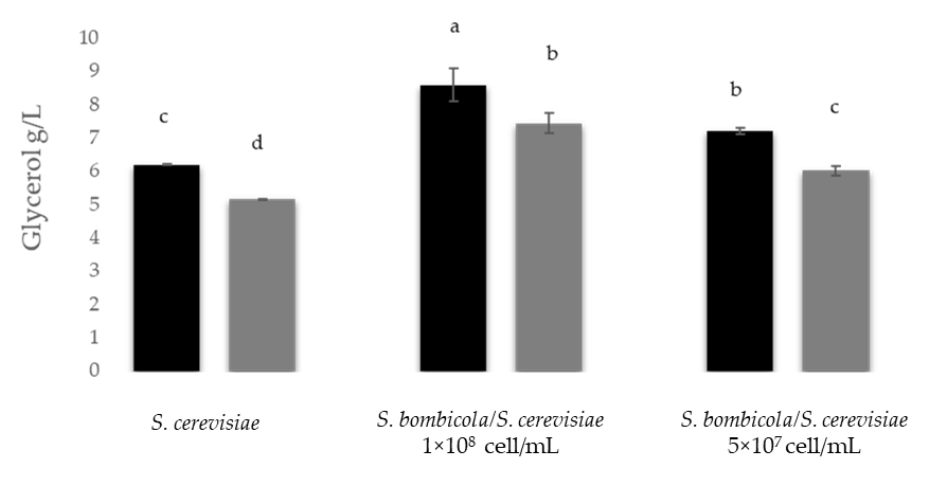

(C)

Figure 1. Ethanol content, (A) volatile acidity, (B) and glycerol content (C) of preliminary screening in sequential fermentation in static and agitation condition in Synthetic Grape Juice. Agitation condition; static condition. Data with different superscript letters $\left({ }^{(\mathrm{a}, \mathrm{b}, \mathrm{c}, \mathrm{d}}\right)$ are different according to Duncan tests $(0.05 \%)$. 
In relation to the volatile acidity (Figure 1B), the fermentation trials at different inoculum level of $S$. bombicola showed in general similar values exhibited by $S$. cerevisiae. A significant increase was detected only with S. bombicola/S. cerevisiae sequential fermentation in static condition using different inoculation levels $(0.53 \mathrm{~g} / \mathrm{L}$ acetic acid). The aeration conditions determined a general enhancement of glycerol production in all fermentation trials. In particular, a significant increase was showed in S. bombicola/S. cerevisiae $1 \times 10^{8}$ cells $/ \mathrm{mL}$ sequential fermentations $(8.58 \mathrm{~g} / \mathrm{L})$ compared with $S$. cerevisiae pure culture with the exception of S. bombicola/S. cerevisiae $5 \times 10^{7}$ cells $/ \mathrm{mL}$ in static condition (Figure 1C).

Considering the similar results obtained and the most practice application in vinery condition of the lower inoculum level, S. bombicola at inoculum level $5 \times 10^{7} \mathrm{cell} / \mathrm{mL}$ was identified for the further bench-top fermentation trials in NGJ. Using the following fermentation conditions: Semi-anaerobic (gently agitation $60 \mathrm{rpm}$ ) and aeration flow of $20 \mathrm{~mL} / \mathrm{L} / \mathrm{min}$ during the first $72 \mathrm{~h}$.

\subsection{Bench-Top Fermentation Trials}

\subsubsection{Biomass Evolution and Sugar Consumption in Natural Grape Juice (NGJ)}

The growth kinetics are reported in Figure 2. The pure S. cerevisiae fermentation (Figure $2 \mathrm{~A}$ ) achieved the maximum cell concentration (c.a. $10^{8}$ cells $/ \mathrm{mL}$ ) in 2 days maintaining this cell concentration until the end of the fermentation. When S. cerevisiae reached the maximum cell concentration, the wild non-Saccharomyces yeasts (WNS) present in the natural grape juice, decreased until disappeared.

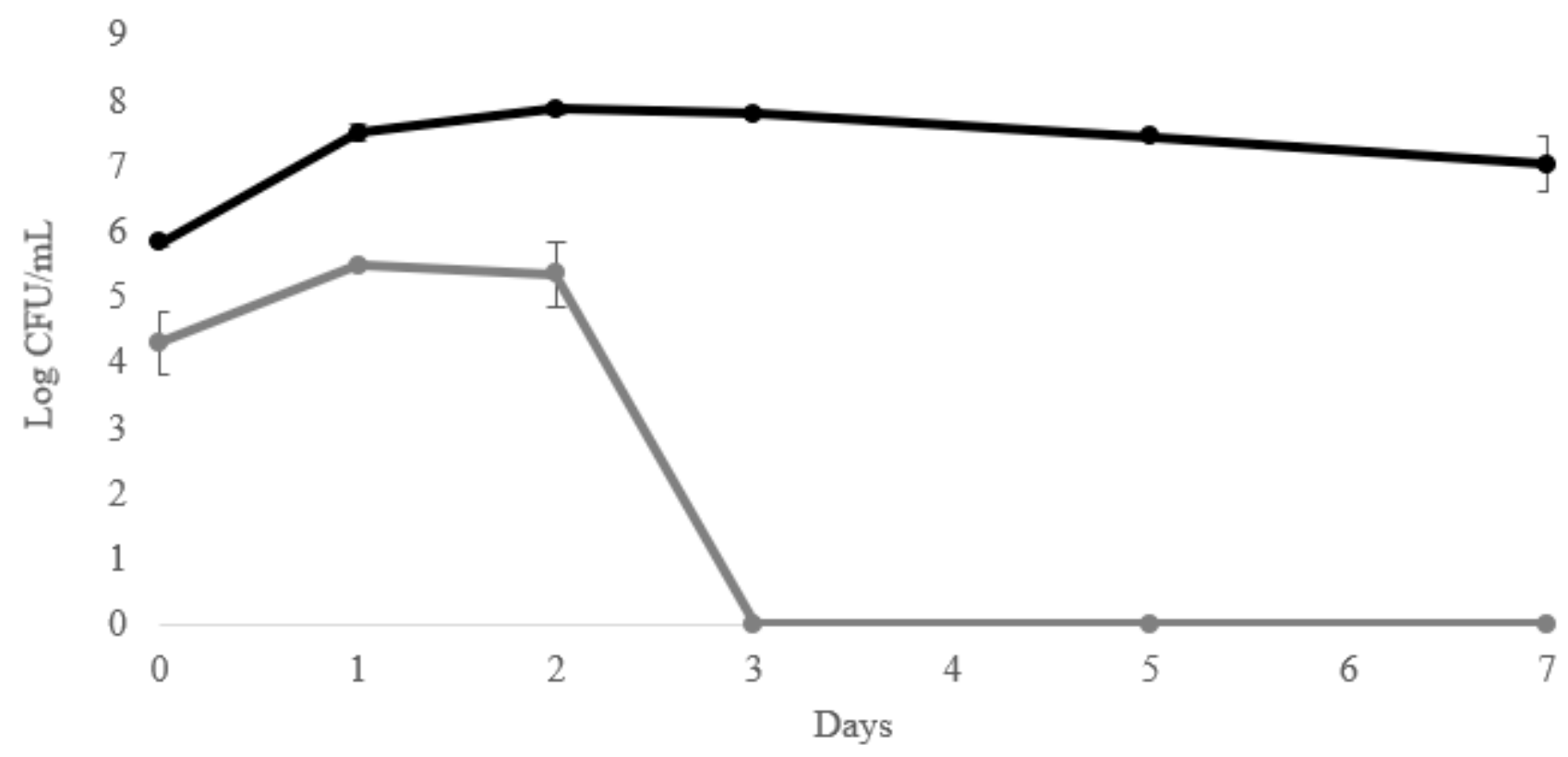

(A)

Figure 2. Cont. 


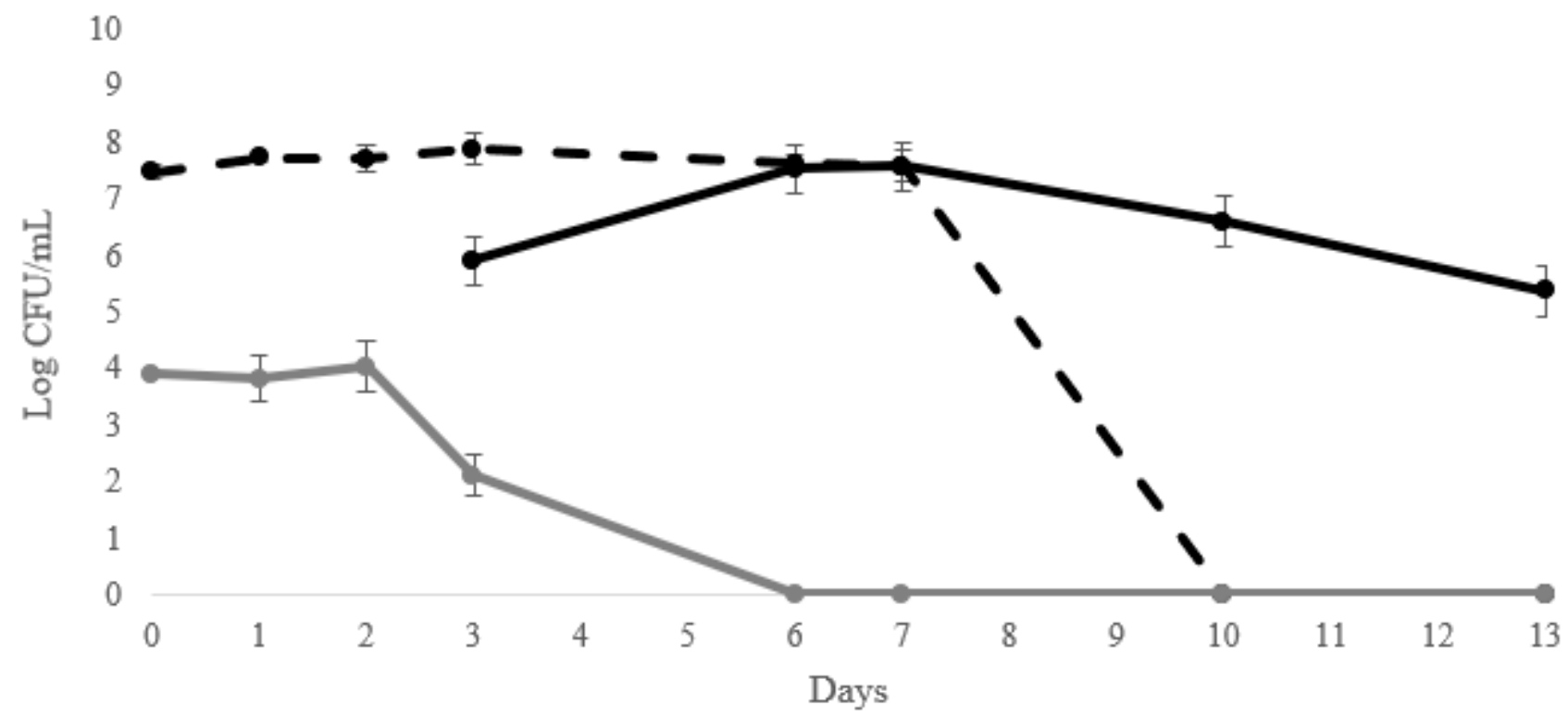

(B)

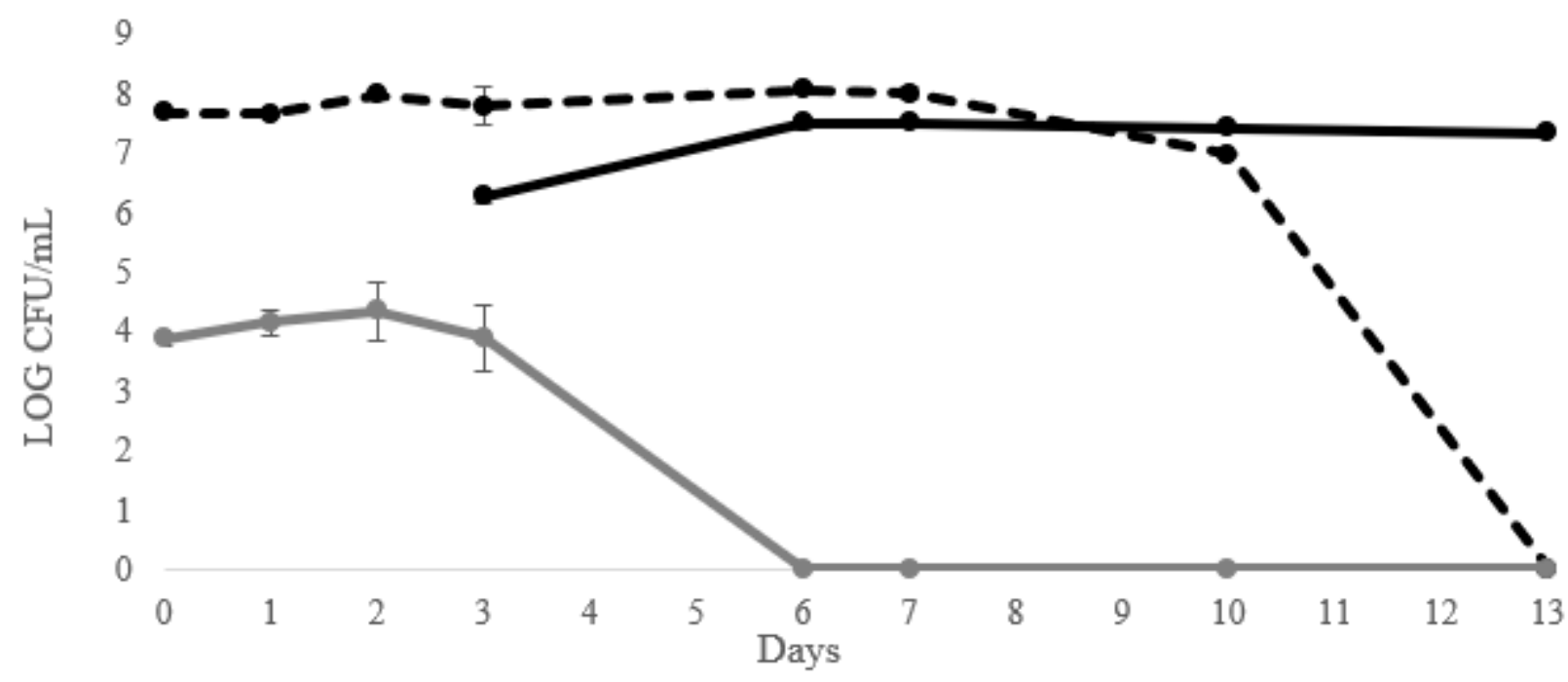

(C)

Figure 2. Growth kinetics in sequential fermentation trials S. bombicola/S. cerevisiae and control S. cerevisiae on natural grape juice (NGJ). (-) S. cerevisiae; ( - ) Wild non-Saccharomyces; ( - - ) S. bombicola. (A) control-pure fermentation with S. cerevisiae inoculum; (B) semi-aerobic condition (no aeration); (C) with aeration $(20 \mathrm{~mL} / \mathrm{L}$ min of air flux during the first $72 \mathrm{~h})$.

A similar trend in biomass evolution of S. cerevisiae and WNS was shown in semianaerobic conditions (Figure 2B). In terms of the S. bombicola population, the differences between semi-anaerobic and air flow addition were shown. The sequential fermentations carried out with air flow $(20 \mathrm{~mL} / \mathrm{L} / \mathrm{min}$ of air flux during the first $72 \mathrm{~h}$ ) (Figure $2 \mathrm{C}$ ) maintained high level $\left(>10^{7} \mathrm{cfu} / \mathrm{mL}\right)$ until the tenth day, while in semi-aerobic condition high biomass concentration where maintained only until seventh day (Figure 2B). Thus, $S$. bombicola fermentation trials with air flow showed a higher persistence of viable cells in comparison with sequential fermentation in semi-anaerobic condition. In relation to the evolution of WNS, S. cerevisiae pure culture showed a strong control of WNS that disappeared on the third day of fermentation, while WNS with S. bombicola/S. cerevisiae 
sequential fermentation disappeared at sixth day of fermentation (in both conditions: with and without air flux).

The duration of fermentation process was approximately 13 days for both the sequential fermentations while $S$. cerevisiae pure culture, as expected, completed the fermentation in 7 days.

The sugar consumption (Figure 3) confirmed the fermentation trend: the sequential fermentations showed a comparable trend S. cerevisiae pure culture exhibited a faster fermentation kinetics with a half of the sugar consumed after $24 \mathrm{~h}$ of fermentation.

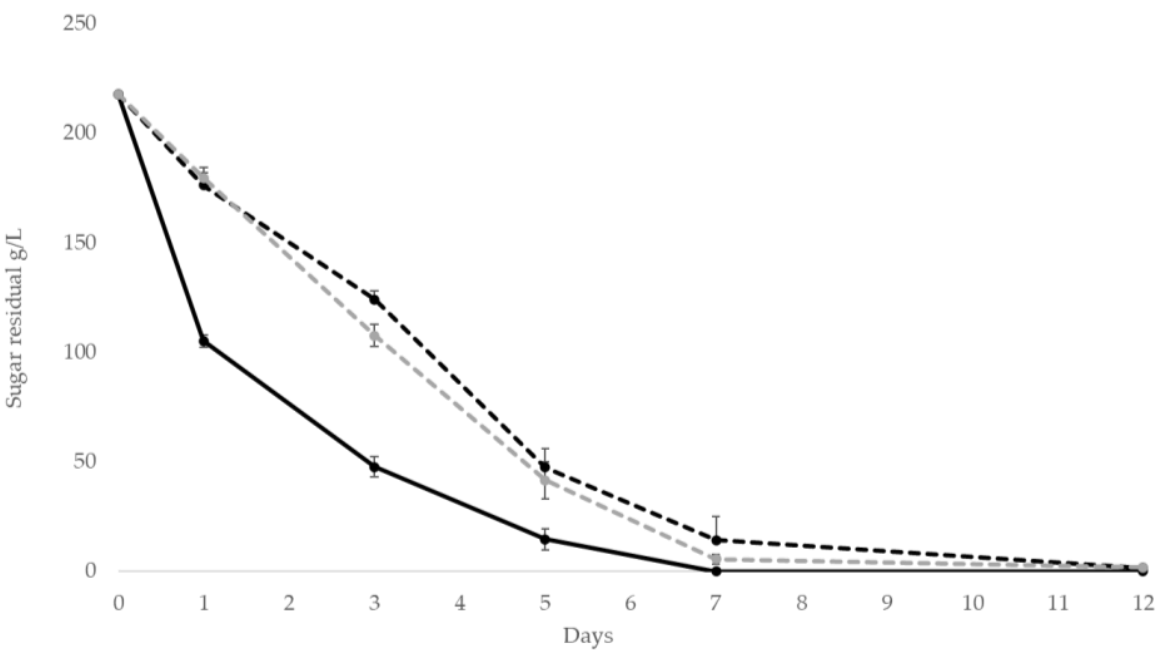

Figure 3. Sugar consumption kinetics in sequential fermentation trials S. bombicola/S. cerevisiae and control S. cerevisiae on natural grape juice (NGJ) in static and aeration condition. $(\longrightarrow)$ S. cerevisiae; (-) S. bombicola/S. cerevisiae static and (--) S. bombicola/S. cerevisiae $20 \mathrm{~mL} / \mathrm{L} / \mathrm{min}$ oxygen.

3.2.2. Main Fermentation Parameters in Natural Grape Juice (NGJ)

The main fermentation parameters determined at the end of fermentation are reported in Table 1.

Table 1. Main parameters of NGJ fermentation trials. The initial sugar concentration was $218 \mathrm{~g} / \mathrm{L}$. Data are means \pm standard deviations from three independent experiments. Data with different superscript letters $\left({ }^{\mathrm{a}, \mathrm{b}, \mathrm{c}}\right)$ within each Column are different according to Duncan tests $(0.05 \%)$.

\begin{tabular}{ccccccc}
\hline Fermentation Trials & $\begin{array}{c}\text { Sugar Consumed } \\
(\mathbf{g} / \mathbf{L})\end{array}$ & $\begin{array}{c}\text { Ethanol } \\
(\mathbf{\%} \text { v/v) }\end{array}$ & $\begin{array}{c}\text { Ethanol Yield } \\
(\mathbf{g} / \mathbf{g}) \mathbf{\%}\end{array}$ & $\begin{array}{c}\text { Glycerol } \\
(\mathbf{g} / \mathbf{L})\end{array}$ & $\begin{array}{c}\text { Volatile Acidity } \\
(\mathbf{a s ~ A c e t i c ~ A c i d ~} \mathbf{~} / \mathbf{L})\end{array}$ & $\begin{array}{c}\text { Succinic Acid } \\
(\mathbf{g} / \mathbf{L})\end{array}$ \\
\hline $\begin{array}{l}\text { S. cerevisiae pure culture } \\
\text { S. bombicola/S. cerevisiae } \\
\text { static condition }\end{array}$ & $218 \pm 0.00^{\mathrm{a}}$ & $12.12 \pm 0.11^{\mathrm{a}}$ & $44.03 \pm 0.46^{\mathrm{a}}$ & $3.08 \pm 0.27^{\mathrm{c}}$ & $0.35 \pm 0.01^{\mathrm{a}}$ & $0.25 \pm 0.21^{\mathrm{b}}$ \\
$\begin{array}{c}\text { S. bombicola/S. cerevisiae } \\
\text { 20 } \mathrm{mL} / \mathrm{L} / \mathrm{min} \text { oxygen }\end{array}$ & $216.44 \pm 0.47^{\mathrm{a}, \mathrm{b}}$ & $11.91 \pm 0.11^{\mathrm{b}}$ & $43.45 \pm 1.13^{\mathrm{a}}$ & $7.30 \pm 0.12^{\mathrm{b}}$ & $0.29 \pm 0.02^{\mathrm{b}}$ & $0.61 \pm 0.14^{\mathrm{b}}$ \\
\hline
\end{tabular}

In relation to the ethanol content, in comparison with S. cerevisiae pure culture, S. bombicola/S.cerevisiae air flow exhibited an ethanol reduction of $1.46 \%(v / v)$. Whereas, S. bombicola/S. cerevisiae static condition led an ethanol reduction of $0.21 \%(v / v)$. This trend was reflected by the ethanol yield that was significant significantly lower in S. bombicola/S. cerevisiae with air flow in comparison with other fermentation trials. While, volatile acidity amounts were comparable among the fermentations, sequential fermentation led a general increase in final glycerol content. In particular, S. bombicola sequential fermentation air flow supplied showed a significant increase in this compound (more than 3-fold of $S$. cerevisiae). However, the results also exhibited an increase in glycerol content in static sequential fermentations, indicating the effect of $S$. bombicola in glycerol production. Aeration condition also determined a significant increase in succinic acid. 


\subsubsection{The Main Volatile Compounds in Natural Grape Juice}

The data of the main volatile compounds are reported in Table 2.

Table 2. The main volatile compounds of S. cerevisiae pure culture and sequential fermentations with or without air flow addition. Data are means \pm standard deviations from three independent experiments. Data with different superscript letters $(\mathrm{a}, \mathrm{b}, \mathrm{c})$ within each Column are different according to Duncan tests $(0.05 \%)$.

\begin{tabular}{cccc}
\hline mg/L & & \multicolumn{2}{c}{ Fermentation Trials } \\
ESTERS & $\begin{array}{c}\text { S. cerevisiae Pure } \\
\text { Culture }\end{array}$ & $\begin{array}{c}\text { S. bombicola/S. cere- } \\
\text { visiae } \\
20 \mathrm{~mL} / \mathrm{L} / \mathrm{min}\end{array}$ & $\begin{array}{c}\text { S. bombicola/S. cere- } \\
\text { visiae semi anaerobic } \\
\text { condition }\end{array}$ \\
\hline Ethyl butyrate & $0.41 \pm 0.02^{\mathrm{a}, \mathrm{b}}$ & $1.08 \pm 0.35^{\mathrm{a}}$ & $0.40 \pm 0.39^{\mathrm{b}}$ \\
Ethyl acetate & $30.58 \pm 1.27^{\mathrm{a}}$ & $26.17 \pm 2.51^{\mathrm{b}}$ & $21.58 \pm 1.04^{\mathrm{c}}$ \\
Ethyl hexanoate & $0.06 \pm 0.004^{\mathrm{a}}$ & $0.04 \pm 0.011^{\mathrm{a}}$ & $0.03 \pm 0.019^{\mathrm{a}}$ \\
Isoamyl acetate & $2.017 \pm 0.05^{\mathrm{a}, \mathrm{b}}$ & $0.91 \pm 0.34^{\mathrm{b}}$ & $2.71 \pm 1.18^{\mathrm{a}}$ \\
\hline ALCOHOLS & & & \\
n-propanol & $34.00 \pm 2.04^{\mathrm{b}}$ & $69.63 \pm 0.06^{\mathrm{a}}$ & $33.74 \pm 0.31^{\mathrm{b}}$ \\
Isobutanol & $14.33 \pm 0.16^{\mathrm{c}}$ & $35.34 \pm 1.21^{\mathrm{a}}$ & $19.43 \pm 2.04^{\mathrm{b}}$ \\
Amyl alcohol & $4.89 \pm 1.77^{\mathrm{a}}$ & $3.82 \pm 0.28^{\mathrm{a}}$ & $1.30 \pm 0.24^{\mathrm{b}}$ \\
Isoamyl alcohol & $64.50 \pm 2.63^{\mathrm{a}}$ & $45.47 \pm 1.36^{\mathrm{b}}$ & $29.31 \pm 0.42^{\mathrm{c}}$ \\
3-Phenyl ethanol & $30.1 \pm 0.018^{\mathrm{a}, \mathrm{b}}$ & $24.8 \pm 0.28^{\mathrm{b}}$ & $35.8 \pm 0.07^{\mathrm{a}}$ \\
\hline CARBONYL & & & \\
COMPOUNDS & & $30.12 \pm 2.22^{\mathrm{a}}$ & $9.26 \pm 0.53^{\mathrm{b}}$ \\
Acetaldehyde & $10.59 \pm 0.19^{\mathrm{b}}$ & & \\
MONOTERPENS & & $0.05 \pm 0.001^{\mathrm{a}}$ & $0.12 \pm 0.05^{\mathrm{a}}$ \\
Linalool & $0.08 \pm 0.01^{\mathrm{a}}$ & $0.007 \pm 0.0004^{\mathrm{b}}$ & $0.10 \pm 0.05^{\mathrm{a}}$ \\
Geraniol & $0.09 \pm 0.018^{\mathrm{a}, \mathrm{b}}$ & &
\end{tabular}

In relation to the higher alcohols, the sequential fermentation trials with air flow led a significant increase in n-propanol and isobutanol in comparison with the other fermentation trials, while amylic alcohol was comparable with $S$. cerevisiae pure culture. On the contrary, the wine obtained with S. bombicola/S. cerevisiae sequential fermentation in aerobic condition, showed a lower amount of $\beta$-Phenyl ethanol (rose aroma) than the other wines.

The behaviour of sequential fermentations was variable in the group of esters compounds. Indeed, it was not possible to define a general trend. Indeed, sequential fermentation with $20 \mathrm{~mL} / \mathrm{L} / \mathrm{min}$ of air flow exhibited a significant increase in ethyl butyrate content than other trials and a comparable amount of ethyl hexanoate with other fermentations.

S. bombicola/S. cerevisiae sequential fermentation in static condition led an increase in isoamyl acetate (banana aroma) content, and a significant decrease of this aroma compound in aerobic condition if compared with $S$. cerevisiae control trial.

S. bombicola/S. cerevisiae sequential fermentation with air flow affected the acetaldehyde content in comparison with other fermentation trials without negative influence on the aromatic profile of wines. In relation to the main mono-terpens (linalool and geraniol), the resulting wines did not show a significant difference.

\section{Discussion}

In recent years, one of the most relevant concerns that is related to the winemaking sector is the progressive increase of ethanol content. Among microbiological strategies proposed to decrease alcohol level in wine is the use of non-Saccharomyces yeasts in cofermentation or sequential fermentation with $S$. cerevisiae starter strains under aerobic and anaerobic conditions were proposed $[24,28,29,31,32,43-48]$. Several studies reported that the use of air flow during the early stage of fermentation affects yeast physiology and metabolism favouring the fermentation performance of yeasts [49-53]. In particular, in 
S. cerevisiae respiration is repressed by high concentrations of sugars even in the presence of oxygen, whereas in general non-Saccharomyces wine yeasts are able to aerobically respire sugar, modulating the production of ethanol, glycerol and other by-products $[28,47,54-56]$.

In this work, the effect of aeration on ethanol content, population dynamics and analytical profile of wines using free cells of $S$. bombicola /S. cerevisiae sequential inoculation were evaluated. S. bombicola strain, used in this work was investigated in a previous work in immobilized form and in anaerobic condition [32], determining an ethanol reduction of $1.6 \%(v / v)$ using $10 \%(w / w)$ of beads corresponding to an inoculation level of $10^{8}$ cells $/ \mathrm{mL}$. Here, a comparable result was obtained $(1.46 \% v / v)$ but with a lower inoculum of free cells $\left(5 \times 10^{7}\right.$ cells $\left./ \mathrm{mL}\right)$ and in presence of initial concentration of $10^{4}$ cells $/ \mathrm{mL}$ of WNS. Free cell inoculation is an easily procedure to apply at industrial level in winemaking sector in comparison to the use of immobilized cells that in the other side allows high inoculum level.

The ethanol reduction achieved in the present work could be, at least in part, explained by the relevant increase in glycerol as previously reported [38]. A similar result was obtained with C. zemplinina (synonym Starmerella bacillaris, a closely related species with similar oenological features of $S$. bombicola), that was widely investigated to produce wines with less ethanol levels and higher glycerol content [26].

On the other hand, these results confirmed that the oxygen addition decreased the ethanol production of $S$. bombicola cells highlighting an increase of growth and sugar utilization kinetics. However, different metabolic behaviour of various non-Saccharomyces species was exhibited with oxygen supplied, highlighting that it is not possible to delineate a general trend within non-Saccharomyces yeasts [57].

S. bombicola in sequential fermentation confirmed the highest production of glycerol and succinic acid as previously reported [38]. Moreover, the results showed a positive role of oxygen on cell growth and development of S. bombicola. On the other hand, this significant enhancement of by-products together with respiration activity do not completely justify the ethanol reduction obtained and other fermentation products that were not evaluated in this investigation need to be explored.

One of the most negative features in mixed or sequential fermentation non-Saccharomy$c e s / S$. cerevisiae yeasts in aeration condition is the increase of acetic acid, compound responsible of sour and bitter taste $[28,48,52,58]$. In this study, S. bombicola in sequential fermentation both in anaerobic and aerobic condition limiting the air flow in the first $72 \mathrm{~h}$ (before the inoculum of $S$. cerevisiae) showed an acetic acid content very closed to that exhibited by $S$. cerevisiae indicating a positive interaction between the two yeast strains.

Conversely, ethyl butyrate and higher alcohols increased with oxygen supplementation. This trend could be related to the oxygen supplementation. Indeed, Valero et al. [59] and Shekhawat et al. [52] showed an increase in the concentration of esters and higher alcohols in aeration condition. The supplementation of oxygen revealed a correlation between higher alcohols content, the growth of non-Saccharomyces yeasts, and oxygen levels. However, it is not possible to define the general effect of oxygen on the volatile profile of the wine. Indeed, different factors, such as yeast strains, fermentation conditions and grape variety may concurrently affect the aroma composition of wines $[31,60,61]$.

In conclusion, the results obtained highlighted the ability of S. bombicola strain DiSVA 66 , in sequential fermentation and under partial aeration conditions, to make wines with reduced alcohol content, thereby maintaining, at the same time, an effective analytical profile. Obviously, it is necessary to set up the modalities of its use in the function of the physiological and fermentation characteristics of the non-Saccharomyces specie/strain.

Author Contributions: L.C., E.G., A.A., F.C. and M.C. contributed equally to this manuscript. All authors participated in the design and discussion of the research. L.C. and E.G. carried out the experimental part of the work. L.C., E.G., A.A., F.C. and M.C. carried out the analysis of the data and wrote the manuscript. All authors have read and agreed to the published version of the manuscript.

Funding: This research received no external funding. 
Institutional Review Board Statement: Not applicable.

Informed Consent Statement: Not applicable.

Conflicts of Interest: The authors declare no conflict of interest.

\section{References}

1. Varela, C.; Dry, P.R.; Kutyna, D.R.; Francis, I.L.; Henschke, P.A.; Curtin, C.D.; Chambers, P.J. Strategies for reducing alcohol concentration in wine. Aust. J. Grape Wine Res. 2015, 21, 670-679. [CrossRef]

2. Cretin, B.N.; Dubourdieu, D.; Marchal, A. Influence of ethanol content on sweetness and bitterness perception in dry wines. LWT 2018, 87, 61-66. [CrossRef]

3. Liguori, L.; Russo, P.; Albanese, D.; Di Matteo, M. Production of low-alcohol beverages: Current status and perspectives. In Food Processing for Increased Quality and Consumption; Academic Press: Cambridge, MA, USA, 2018; pp. 347-382.

4. Bindon, K.; Varela, C.; Kennedy, J.; Holt, H.; Herderich, M. Relationships between harvest time and wine composition in Vitis vinifera L. cv. Cabernet sauvignon 1. Grape and wine chemistry. Food Chem. 2013, 138, 1696-1705. [CrossRef] [PubMed]

5. Alston, J.M.; Fuller, K.B.; Lapsley, J.T.; Soleas, G. Too much of a good thing? Causes and consequences of increases in sugar content of California wine grapes. J. Wine Econ. 2011, 6, 135-159. [CrossRef]

6. Godden, P.; Wilkes, E.; Johnson, D. Trends in the composition of Australian wine 1984-2014. Aust. J. Grape Wine Res. 2015, 21, 741-753. [CrossRef]

7. Mozell, M.R.; Thach, L. The impact of climate change on the global wine industry: Challenges \& solutions. Wine Econ. Policy. 2014, 3, 81-89.

8. Goold, H.D.; Kroukamp, H.; Williams, T.C.; Paulsen, I.T.; Varela, C.; Pretorius, I.S. Yeast's balancing act between ethanol and glycerol production in low-alcohol wines. Microb. Biotechnol. 2017, 10, 264-278. [CrossRef]

9. Maturano, Y.P.; Mestre, M.V.; Kuchen, B.; Toro, M.E.; Mercado, L.A.; Vazquez, F.; Combin, M. Optimization of fermentationrelevant factors: A strategy to reduce ethanol in red wine by sequential culture of native yeasts. Int. J. Food Microbiol. 2019, 289, 40-48. [CrossRef]

10. Grønbæk, M. The positive and negative health effects of alcohol- and the public health implications. J. Intern. Med. 2009, 265, 407-420. [CrossRef]

11. Sharma, A.; Vandenberg, B.; Hollingsworth, B. Minimum Pricing of Alcohol versus Volumetric Taxation: Which Policy Will Reduce Heavy Consumption without Adversely Affecting Light and Moderate Consumers? PLoS ONE 2014, 9, e80936. [CrossRef]

12. Annunziata, A.; Pomarici, E.; Vecchio, R.; Mariani, A. Do consumers want more nutritional and health information on wine labels? Insights from the EU and USA. Nutrients 2016, 8, 416. [CrossRef]

13. Jackson, R.S. (Ed.) Wine Science, 4th ed.; Academic Press: Cambridge, MA, USA, 2014; pp. 1-19.

14. King, E.S.; Dunn, R.L.; Heymann, H. The influence of alcohol on the sensory perception of red wines. Food Qual. Pref. 2013, 28, 235-243. [CrossRef]

15. Gawel, R.; Sluyter, S.V.; Waters, E.J. The effects of ethanol and glycerol on the body and other sensory characteristics of Riesling wines. Aust. J. Grape Wine Res. 2007, 13, 38-45. [CrossRef]

16. Escudero, A.; Campo, E.; Fariña, L.; Cacho, J.; Ferreira, V. Analytical characterization of the aroma of five premium red wines. Insights into the role of odor families and the concept of fruitiness of wines. J. Agric. Food Chem. 2007, 55, 4501-4510. [CrossRef] [PubMed]

17. Robinson, A.L.; Ebeler, S.E.; Heymann, H.; Boss, P.K.; Solomon, P.S.; Trengove, R.D. Interactions between wine volatile compounds and grape and wine matrix components influence aroma compound headspace partitioning. J. Agric. Food Chem. 2009, 57, 10313-10322. [CrossRef] [PubMed]

18. Wilkinson, K.; Jiranek, V. Wine of reduced alcohol content: Consumer and society demand vs industry willingness and ability to deliver. In Proceedings of the 1st International Symposium on Alcohol Level Reduction in Wine Oenoviti International Network, Bordeaux, France, 6 September 2013.

19. Tilloy, V.; Ortiz-Julien, A.; Dequin, S. Reduction of ethanol yield and improvement of glycerol formation by adaptive evolution of the wine yeast Saccharomyces cerevisiae under hyperosmotic conditions. Appl. Environ. Microbiol. 2014, 80, 2623-2632. [CrossRef] [PubMed]

20. Frost, S.C.; Harbertson, J.F.; Heymann, H. A full factorial study on the effect of tannins, acidity, and ethanol on the temporal perception of taste and mouthfeel in red wine. Food Qual. Prefer. 2017, 62, 1-7. [CrossRef]

21. Kutyna, D.R.; Varela, C.; Stanley, G.A.; Borneman, A.R.; Henschke, P.A.; Chambers, P.J. Adaptive evolution of Saccharomyces cerevisiae to generate strains with enhanced glycerol production. Appl. Environ. Microbiol. 2012, 93, 1175-1184. [CrossRef]

22. Canonico, L.; Solomon, M.; Comitini, F.; Ciani, M.; Varela, C. Volatile profile of reduced alcohol wines fermented with selected non-Saccharomyces yeasts under different aeration conditions. Food Microbiol. 2019, 84, 103-247. [CrossRef]

23. Longo, R.; Blackman, J.W.; Antalick, G.; Torley, P.J.; Rogiers, S.Y.; Schmidtke, L.M. A comparative study of partial dealcoholisation versus early harvest: Effects on wine volatile and sensory profiles. Food Chem. 2018, 261, 21-29. [CrossRef]

24. Ciani, M.; Morales, P.; Comitini, F.; Tronchoni, J.; Canonico, L.; Curiel, J.A.; Oro, L.; Rodrigues, A.J.; Gonzalez, R. Non-conventional yeast species for lowering ethanol content of wines. Front. Microbiol. 2016, 7, 642. [CrossRef] 
25. Varela, J.; Varela, C. Microbiological strategies to produce beer and wine with reduced ethanol concentration. Food Biotechnol. 2019, 56, 88-96. [CrossRef] [PubMed]

26. Ciani, M.; Comitini, F. Use of non-Saccharomyces yeasts in red winemaking. In Red Wine Technology; Antonio, M., Ed.; Elsevier: Amsterdam, The Netherlands, 2019; pp. 51-68.

27. Contreras, A.; Hidalgo, C.; Henschke, P.A.; Chambers, P.J.; Curtin, C.; Varela, C. Evaluation of non-Saccharomyces yeasts for the reduction of alcohol content in wine. Appl. Environ. Microbiol. 2014, 80, 1670-1678. [CrossRef]

28. Contreras, A.; Hidalgo, C.; Schmidt, S.; Henschke, P.A.; Curtina, A.; Varela, C. The application of non-Saccharomyces yeast in fermentations with limited aeration as a strategy for the production of wine with reduced alcohol content. Int. J. Food Microbiol. 2015, 205, 7-15. [CrossRef] [PubMed]

29. Varela, C. The impact of non-Saccharomyces yeasts in the production of alcoholic beverages. Appl. Microbiol. Biotechnol. 2016, 100, 9861-9874. [CrossRef]

30. Longo, R.; Blackman, J.W.; Torley, P.J.; Rogiers, S.Y.; Schmidtke, L.M. Changes in volatile composition and sensory attributes of wines during alcohol content reduction. J. Sci. Food Agric. 2017, 97, 8-16. [CrossRef] [PubMed]

31. Canonico, L.; Comitini, F.; Ciani, M. Metschnikowia pulcherrima selected strain for ethanol reduction in wine: Influence of cell immobilization and aeration condition. Foods 2019, 8, 378. [CrossRef] [PubMed]

32. Canonico, L.; Comitini, F.; Oro, L.; Ciani, M. Sequential fermentation with selected immobilized Non-Saccharomyces yeast for reduction of ethanol content in wine. Front. Microbiol. 2016, 7, 287. [CrossRef] [PubMed]

33. Comitini, F.; Gobbi, M.; Domizio, P.; Romani, C.; Lencioni, L.; Mannazzu, I.; Ciani, M. Selected non-Saccharomyces wine yeasts in controller multi starter fermentations with Saccharomyces cerevisiae. Food Microbiol. 2011, 28, 873-882. [CrossRef]

34. Domizio, P.; Romani, C.; Lencioni, L.; Comitini, F.; Gobbi, M.; Mannazzu, I.; Ciani, M. Outlining a future for non-Saccharomyces yeasts: Selection of putative spoilage wine strains to be used in association with Saccharomyces cerevisiae for grape juice fermentation. Int. J. Food Microbiol. 2011, 147, 170-180. [CrossRef]

35. Jolly, N.P.; Varela, C.; Pretorius, I.S. Not your ordinary yeasts: Non-Saccharomyces yeasts in wine production uncovered. FEMS Yeast Res. 2014, 14, 215-237. [CrossRef] [PubMed]

36. Capozzi, V.; Garofalo, C.; Chiriatti, M.A.; Grieco, F.; Spanoa, G. Microbial terroir and food innovation: The case of yeast biodiversity in wine. Microbiol. Res. 2015, 181, 75-83. [CrossRef]

37. Englezos, V.; Rantsiou, K.; Cravero, F.; Torchio, F.; Ortiz-Julien, A.; Gerbi, V.; Rolle, L.; Cocolin, L. Starmerella bacillaris and Saccharomyces cerevisiae mixed fermentations to reduce ethanol content in wine. Appl. Microbiol. Biotechnol. 2016, 100, 5515-5526. [CrossRef] [PubMed]

38. Ciani, M.; Ferraro, L. Combined used of immobilized Candida stellata cells and Saccharomyces cerevisiae to improve the quality of wines. J. Appl. Microbiol. 1998, 85, 247-254. [CrossRef] [PubMed]

39. Lin, Y. Detection of wild yeasts in the brewery efficiency of differential media. J. Inst. Brew. 1975, 81, 410-417. [CrossRef]

40. Community Reference Methods for the Analysis of Spirits Drinks. Available online: https://op.europa.eu/en/publicationdetail/- / publication/792feac2-0f81-47db-8097-32c229a38650/language-en (accessed on 19 December 2000).

41. Canonico, L.; Comitini, F.; Ciani, M. Torulaspora delbrueckii for secondary fermentation in sparkling wine production. Food Microbiol. 2018, 74, 100-106. [CrossRef]

42. Canonico, L.; Ciani, E.; Galli, E.; Comitini, F.; Ciani, M. Evolution of aromatic profile of Torulaspora delbrueckii mixed fermentation at microbrewery plant. Fermentation 2020, 6, 7. [CrossRef]

43. Englezos, V.; Rantsiou, K.; Cravero, F.; Torchio, F.; Pollona, M.; Fracassetti, D.; Ortiz-Julien, A.; Gerbi, V.; Rolle, L.; Cocolin, L. Volatile profile of white wines fermented with sequential inoculation of Starmerella bacillaris and Saccharomyces cerevisiae. Food Chem. 2018, 257, 350-360. [CrossRef]

44. Furlani Mestre, M.V.; Maturano, Y.P.; Combina, M.; Mercado, L.A.; Toro, M.E.; Vazquez, F. Selection of non-Saccharomyces yeasts to be used in grape musts with high alcoholic potential: A strategy to obtain wine with reduced etanol content. FEMS Yeast Res. 2017, 17. [CrossRef]

45. Rolle, L.; Englezos, V.; Torchio, F.; Cravero, F.; Segade, S.R.; Rantsiou, K.; Giacosa, S.; Gambuti, A.; Gerbi, V.; Cocolin, L. Alcohol reduction in red wines by technological and microbiological approaches: A comparative study. Aust. J. Grape Wine Res. 2018, 24, 62-74. [CrossRef]

46. Alonso-del-Real, J.; Lairón-Peris, M.; Barrio, E.; Querol, A. Effect of temperature on the prevalence of Non Saccharomyces cerevisiae species against a $S$. cerevisiae wine strain in wine fermentation: Competition, physiological fitness, and influence in final wine composition. Front. Microbiol. 2017, 8, 150. [CrossRef]

47. Quiros, M.; Rojas, V.; Gonzalez, R.; Morales, P. Selection of non-Saccharomyces yeast strains for reducing alcohol levels in wine by sugar respiration. Int. J. Food Microbiol. 2014, 181, 85-91. [CrossRef]

48. Rocker, J.; Strub, S.; Ebert, K.; Grossmann, M. Usage of different aerobic non-Saccharomyces yeasts and experimental conditions as a tool for reducing the potential ethanol content in wines. Eur. Food Res. Technol. 2016, 242, 2051-2070. [CrossRef]

49. Blateyron, L.; Sablayrolles, J. Stuck and slow fermentations in enology: Statistical study of causes and effectiveness of combined additions of oxygen and diammonium phosphate. J. Biosci. Bioeng. 2001, 91, 184-189. [CrossRef]

50. Fornairon-Bonnefond, C.; Aguera, E.; Deytieux, C.; Sablayrolles, J.M.; Salmon, J.M. Impact of oxygen addition during enological fermentation on sterol contents in yeast lees and their reactivity towards oxygen. J. Biosci. Bioeng. 2003, 95, 496-503. [CrossRef] 
51. Aceituno, F.F.; Orellana, M.; Torres, J.; Mendoza, S.; Slater, A.W.; Melo, F.; Agosin, E. Oxygen response of the wine yeast Saccharomyces cerevisiae EC1118 grown under carbon-sufficient, nitrogen-limited enological conditions. Appl. Microbiol. Biotechnol. 2012, 78, 8340-8352. [CrossRef] [PubMed]

52. Shekhawat, K.; Porter, T.J.; Bauer, F.F.; Setati, M.E. Employing oxygen pulses to modulate Lachancea thermotolerans-Saccharomyces cerevisiae Chardonnay fermentations. Ann. Microbiol. 2018, 68, 93-102. [CrossRef]

53. Tronchoni, J.; Curiela, J.A.; Sáenz-Navajas, M.P.; Morales, P.; de-la-Fuente-Blanco, A.; Fernández-Zurbanoa, P.; Ferreira, V.; Gonzalez, R. Aroma profiling of an aerated fermentation of natural grape must with selected yeast strains at pilot scale. Food Microbiol. 2018, 70, 214-223. [CrossRef] [PubMed]

54. Alexander, M.; Jeffries, T. Respiratory efficiency and metabolite partitioning as regulatory phenomena in yeasts. Enzym. Microb. Technol. 1990, 12, 2-19. [CrossRef]

55. De Deken, R.H. The crabtree effect: A regulatory system in yeast. J. Gen. Microbiol. 1966, 44, 149-156. [CrossRef]

56. Morales, P.; Rojas, V.; Quirós, M.; Gonzalez, R. The impact of oxygen on the final alcohol content of wine fermented by a mixed starter culture. Appl. Microbiol. Biotechnol. 2015, 99, 3993-4003. [CrossRef] [PubMed]

57. Ivit, N.N.; Longo, R.; Kemp, B. The effect of non-Saccharomyces and Saccharomyces non-cerevisiae yeasts on ethanol and glycerol levels in wine. Fermentation 2020, 6, 77. [CrossRef]

58. Ribéreau-Gayon, P.; Glories, Y.; Maujean, A.; Dubourdieu, D. Alcohols and other volatile compounds. In Handbook of Enology: The Chemistry of Wine Stabilization and Treatments; Ribéreau-Gayon, P., Glories, Y., Maujean, A., Dubourdieu, D., Eds.; John Wiley \& Sons: Chichester, UK, 2006; pp. 51-64.

59. Valero, E.; Moyano, L.; Millan, M.C.; Medina, M.; Ortega, J.M. Higher alcohols and esters production by Saccharomyces cerevisiae. Influence of the initial oxygenation of the grape must. Food Chem. 2002, 78, 57. [CrossRef]

60. Benito, Á.; Calderón, F.; Benito, S. The influence of non-Saccharomyces species on wine fermentation quality parameters. Fermentation 2019, 5, 54. [CrossRef]

61. Binati, R.L.; Wilson, J.F.L.J.; Luzzini, G.; Slaghenaufi, D.; Ugliano, M.; Torriani, S. Contribution of non-Saccharomyces yeasts to wine volatile and sensory diversity: A study on Lachancea thermotolerans, Metschnikowia spp. and Starmerella bacillaris strains isolated in Italy. Int. J. Food Microbiol. 2020, 318, 108470. [CrossRef] [PubMed] 